\title{
Environmental, social and economic factors in sustainable development with food, energy and eco-space aspect security
}

\author{
Piotr F. Borowski ${ }^{1 *}$, Iaroslav Patuk ${ }^{2}$ \\ 1 Warsaw University of Life Sciences, Institute of Mechanical Engineering, 166 Nowoursynowska \\ street 02-787 Warsaw, Poland \\ 2 Graduate School of Science and Technology Niigata University, JAPAN phone: +81 703966 6508; \\ +7953229 2629, e-mail: yaroslavpatuk93@gmail.com \\ * Corresponding author: pborowski@autograf.pl, phone: +48 889730300
}

Keywords: Sustainable development, agriculture, food security, energy sector, welfare

\begin{abstract}
Highlights: The main scientific problem, addressed by the study was undertaken in order to help facilitate a positive outcome on the energy and agricultural sectors connected with climate change and environmental law. It was found that there is an extremely strong positive correlation (from 0.8 to 1.0 ), and a very strong negative correlation (from -0.8 to -1.0 ) between the levels of a country's age share, $\mathrm{CO}_{2}$ emissions, renewable energy consumption, and natural resources depletion.
\end{abstract}

\begin{abstract}
Sustainable development is now a key factor in the global economy. Sustainable development is a process that leads to the satisfaction of the current needs of people and at the same time goes towards further development without destroying and limiting the possibilities of meeting the needs of future generations. Therefore, joint efforts should be made as soon as possible to build a sustainable and safe future for all people and the planet as a whole. Therefore, it is important to promote and support sustainable development by managing natural resources and ecosystems and the entire environment including people. The presented research was done on-site in African and European countries (Egypt, Ethiopia, Guinea, Turkey, and Poland) to determine their level of sustainable development. The level of sustainable development was determined by selected indicators from the Human Development Index. The level of sustainable development was determined by selected indicators from the Human Development Index. In this study, the authors used basic methods of social and economic research as follows: (1) market observation, (2) primary research on-site and (3) secondary research and the use of statistical analysis (Pearson Correlation). These methods were used to define the social and scientific problems and identify factors that affected a country's sustainable development. The main scientific problem, addressed by the study was undertaken in order to help facilitate a outcome on the energy, food and agricultural sectors connected with climate change and environmental law. It was found that there is an extremely strong positive correlation (from 0.8 to 1.0 ), and a very strong negative correlation (from -0.8 to -1.0 ) between the levels of a country's age share, $\mathrm{CO}_{2}$ emissions, renewable energy consumption, and natural resources depletion.
\end{abstract}

\section{Introduction}

All aspects of sustainable development force us to formulate a new approach to how we perceive the environment and understand the world we live in. The world understood as one that exists as one common system or organism - a system that connects space and time. When we consider the world a system beyond space, we begin to understand that air pollution from North American power plants affects air quality in Europe and 
Africa, and that the 2011 Fukushima nuclear station disaster (Japan) continues affecting human health and may harm fish resources off the coast of Australia (Ochi, 2020). The Fukushima nuclear accident remains an ongoing problem for marine radioecology (Bataille 2015). Recently, we can witness and observe how the new version of the Wuhan coronavirus has the power and power to influence the economy around the world. The influence of China, technology and technical knowledge on the world economy, and the importance of a strong Chinese economy with enormous domestic growth potential are easily discernible in many industries. (Bloom et al. 2021, Lo 2021).

This is particularly evident in trademarks and brands that respond very quickly to the outbreak of a new dangerous, deadly coronavirus. For example, two companies located in Wuhan, Honda, and General Motors, declared that they are discussing on whether or not to open their production again. The world needs to be understood as a whole, complete entity consisting of individual, separate independent regions and lands that interact (Nir 2012).

Therefore, if we think of the world around us as a system over the time, we can begin to understand and realize that the various, multilateral solutions which were used by our predecessors and particularly of our grandparents' generation, (e.g., how to cultivate the agricultural land) continue to influence agricultural practices and the economic policies and practices that we promote today. These solutions and practices have a significant characteristic that impact on current and future generations. If we use a new technology e.g. biochars (EngBC), we should know or we should predict what will be its influence and impact for next generation, for our future (Duan et al. 2019).

Sustainable development and all issues related to this problem have been defined and described and presented in many places and many different ways, but there is one definition that is the most generally accepted, and most often cited which comes from the Brundtland report (3.27). Sustainable development is an increase that meets and realize the needs of the society of the nowadays, without detriment or any damage to the ability of the next generations to fulfil and achieve their own needs. This means satisfying different expectations or trying to meet the varied expectations and needs of all people at the present time and in the future society, (i) promoting personal wellbeing; (ii) social cohesion, closeness and inclusion; and (iii) creating equal opportunities (Magis, 2010).

From the agricultural and food aspect, the three points mentioned above regarding sustainable development can be determined as:

a) Food Security - keeping and sustaining the production of food. The issue of food security and food protection requires constant monitoring, attention and vigilance in matters related to production and distribution. This security can be reinforced by various incentives that often manifest themselves as incentives for agricultural reforms and new, better policies to protect vulnerable farmers, pastoralists and landless people.

b) Species and Ecosystems - from the environmental point of view these can be understood as natural resources, part of the common-wealth to be used for continuous development. The protection and safeguarding of the environment as well as the conservation of living natural resources - (e.g., microorganisms, animals, plants, etc., and non-living elements of the environment, they depend on) - is essential for development. 
c) Energy and Power - their sources and their relationship to the environment and development need careful consideration. Energy and all aspects of power are necessary for the quotidian existence of society and its survival. Future development substantially depends on its perennial availability in growing quantities from sources that are reliable, safe, and environmentally friendly. Nowadays, there is no single source or multifactorial sources at hand to satisfy these forthcoming needs. These three elements create links with each other and are analyzed in detail in the literature as nexus water energy food (Borowski 2020, Purwanto et al. 2021).

In recent years, a number of detailed studies have been carried out in the field of micro and macroeconomics and their analyses and conclusions have influenced and impacted on the growth-oriented agrarian policies. In this wide subject of sustainability the social value is also important indicator (Ravenscroft 2019; Rawluk et al. 2019). Many studies too have presented evidence that the achievements in increasing food production have been reached at the costs of depleting the environmental and natural resources, in such a way that they are irretrievable for the sustainability of any agricultural systems (Kasem \& Thapa, 2012). Intensive, destructive economy should give way to sustainable development. Sustainable development and sustainability have become issues of global policies over the past last two decades. Systematically implemented and subject to constant transformation, the agricultural industry, requires constant tracking and monitoring so that the connections and interactions occurring in agricultural areas and their assessment in regards to set goals can be measured. This will enable adaptive management in various local agricultural systems, which in turn make up global agriculture. New solutions and innovations concerning increasing efficiency of investments in agriculture (private and public investments) is essential to addressing food insecurity in Africa (Pretty, Morison \& Hine, 2003). Moreover, improving agricultural productivity is essential to addressing food insecurity in African countries (Hamann 2020). Measuring in respect of agricultural value-added, Africa's agricultural productivity is on the rise but remains well below the global average. The generation of working youth is disprotionatly affected by the food scarcity.

\subsection{Energy - Impact on environment}

Energy understood as a life-sustaining force, as well as a driving force is an indispensable and in today's world. For example, we use a variety of energy sources (fossil fuels, renewable energy, animal and human) to generate and transfer electricity needed for everyday life. In addition, the future development of energy and its universal availability is an extremely important issue and depends on the possibility of providing access to it for all those who demand it in constantly growing economies, assuming that this energy comes from sources that are reliable, safe and environmentally friendly (Chen, Wu, 2017). In the twenty-first century, the major problem related to energy sources, whether there is one, or a variety of source is that the constantly growing energy needs often exceed the country's supply. At present, the main energy sources are mostly unrenewable (e.g., natural gas, oil, coal, peat moss, and conventional nuclear power). Although it is worth noting that there is currently a shift towards renewable energy 
sources, which have great potential as they are almost unlimited (e.g. Plants, wood, manure, geothermal sources, falling water, solar energy, tidal energy, wind, and wave energy), as well as human strength and animal muscle strength. Sustainable development using renewable energy sources and at the same time maintaining the efficiency of ecosystems in the constantly growing economy and society is a current task for the modern world (Shao 2020). The constantly growing demand for energy is the result of economic development, industrial growth, urbanization trends, as well as the increase in the well-being and prosperity of society. These factors regarding the development of economies of developed countries have led to a very uneven global allocation of primary energy expenditure. Numerous studies carried out in recent years provide empirical evidence that, despite the significant improvement in efficiency associated with the use and exploitation of natural resources, the total consumption of energy resources has not stopped growing (Freire-González, Vivanco \& Puig-Ventosa, 2017).

The side effects of inadequately secured RES energy production processes or excessive interference of the renewable energy infrastructure with the environment in developing countries constitute a social and environmental problem (Rehbein 2020). Widespread and serious health problems, such as, eye and lung diseases (conjunctivitis, emphysema and others) are common, in developing countries due to wood smoke and gas emission. If agricultural and rural wastes are burnt, the residue from pesticides and the like can be inhaled from the fumes and cause health problem. The same applies to emissions from car exhausts. If agriculture producers do not follow the machinery emission classes as requirement, it can have an affect not only on human health but also on the environment.

There are also issues with modern liquid and solid biofuel because they have their own particular danger and risk. Likewise, emissions from solid fuel furnaces have a strong influence on air quality (Huang et al. 2021). Emission from liquid, for example, such fuels as methanol may produce acrid, biting or poisonous fumes. Unlike arable crops on fertile agricultural land, plant production on poor soils also generates quite large amounts of organic residue, and if there is no suitable way to manage this, whether in the form of organic fertilizers, manure or compost, they can cause significant local water pollution.

All the above mentioned problems as well as other issues related to pollution management, regardless of whether they are small, medium or large, will grow in parallel with the development of renewable energy systems. Agriculture worldwide is only a silent energy consumer and we should consider all possibilities to boost and to enhance sustainable development of energy.

\subsection{Species and ecosystems - resources for development}

A clean environment is a prerequisite for health and well-being. However, the interaction between the environment and human health and other living species is very complex. The safeguarding and support of natural resources are a key development issue (Newsome, Moore, \& Dowling, 2012). Adverse changes in the natural environment, the condition of which may often exceed the adaptability and protective barriers of a living 
organism, significantly reduce the chance of survival of most species, including humans. The fundamental question is to determine what are the most important factors regarding the disappearance or extinction of species and endangered ecosystems being caused by government policies in regards to natural resources The impact of climate change has led to increased expenses for public and state-owned organizations, for example, losses incurred due to the cost of compensation for various types of environmental disasters for private households or rebuilding and restoring of destroyed state-owned infrastructure (Bachner, Bednar-Friedl, Knittel, 2019). Governments should accept a new approach and create new models in this field (Rodrik, 2008). However, modern models of technological and scientific development processes for sustainable growth mean that the relationship between fundamental and applied sciences are interactive and complex, and this also applies to the role for targeted, applied research and development by state institutions, even in developed countries (Fuglie, 2016). The human body reacts in a very characteristic way to negative external factors. This is especially true when these factors affect a person in a continuous or very frequent manner. Within some frameworks, adaptation mechanisms alone can ensure full health, even when the effects of harmful factors are prolonged. However, when the adjustment norms are exceeded, the functioning of the organism is disturbed (Scott 2020). Then, disease states and symptoms appear with a wide range of both physical and mental ailments, which are a consequence of disturbances in the functions of individual systems. Therefore, governments should review programs in areas such as agriculture and forestry in the light of this problem. In addition, they should identify and recommend how people and the environment are to be kept safe from harm or injury and indicate in what way such areas can contribute to national development objectives.

As it is widely known and officially demonstrated, basically all or most countries have limited resources allocated and dedicated to the implementation of conservation priorities. Furthermore, the most critical question nowadays is how to use these resources most efficiently.

\subsection{Food security and protection- sustaining the potential}

The issue related to the consumption of food, meaning the receiving and consuming of nutrients, in the appropriate amount and quality food in order to support human existence and basic life. The demand for food in the present, continually developing world will grow systematically along with the development of societies, i.e. increase in population and change of eating habits and moving towards new consumer behaviors (Boserup, 2017). Global food security relies on many elements, not only on rising global production but also on reducing interference and distortions in the structure of the world's global food market and shifting food production from rich countries to developing countries with food deficit regions and districts.

Global food safety and protection also depends on ensuring that all populations, including even the poorest of the poor, can receive some food.

Edibles consumption also varies across countries and individuals depending on preferences, traditional tastes, prices, and product distribution. In developed countries, 
access to food is quite sophisticated, while in poor countries it is at a basic level. In general, food uncertainty varies over time and across space. It depends on food accessibility (Chavas, 2017). While on a global scale, this challenge requires a reassessment of world food distribution, the goal should be considered more immediately and profoundly by national governments. Rapid, robust and sound agricultural development will overall mean not only more possibilities of food consumption but also more wide and different opportunities for people to earn money to purchase food (Oerke, Dehne, Schönbeck, \& Weber, 2012). When countries with under-used agricultural resources source food by importing from outside, they are effectively importing unemployment. Therefore, interventions that improve and raise the level of food security and ensure basic needs and greater self-sufficiency may go some ways in addressing this issue.

\section{Materials and Methods}

This study relied upon quantitative methods of economics research as follows: (1) market observation, (2) primary research, and (3) secondary research (desk research) (Creswell, Creswell, 2017). Plus, observational research carried out on-site within the African continent (selected countries: Egypt, Ethiopia, and Guinea) as well as in the European continent (Poland, and Turkey) from 2015 to 2019. Observations and primary research in Egypt were conducted in November 2015 and March 2016. In Ethiopia the research were realized in May-June 2016. In Guinea the study were realized directly within April-May and August-September 2015. In Turkey research were made in April 2018 and June 2019. The study desk research concerning all mentioned countries was realized as on-going study. The interviews in every mentioned country were realized on the group of young people (students, workers) and academic staff during my stays in mentioned periods.

The main method used in this study was qualitative research. Qualitative data and information for the research process was collected from: focus groups, in-depth and observational interviews (Belk, 2013). As mentioned above, the respondents were people from individual countries. The methods mentioned above were used to define and determine the scientific issue and identify determinants.

The main scientific problem, posed in the study was to fix and establish a positive impact on the energy sector and agricultural sector related to climate change and environmental law and ascertain which factors affect the functioning of those sectors in mentioned countries

Desk based research was carried out by a review of available sources published so far. Text mining methods and techniques, as well as text analysis, were also utilized in this scientific research in order to extract facts and to gain valuable and high-quality data from source materials (Chu, Ke, 2017). A secondary source which was used to collect basic data and information came from internal sources of the European Union (EU) database, incl. Human Development Report, that were then used for statistical analysis. The EU database includes publications by governmental, states and non-governmental institutions, free access data on the internet to reliable and trusted publications as well as in professional magazines and newspapers, in annual reports of companies and commercial databases, public reference materials (mainly provided by national statistics' offices), industry publications, media reports, and scientific journals.

Moreover, the source of the main texts is The United Nations (UN) Documents Gathering a body of global agreements. Therefore, according to UN data, the Pearson 
correlation was used in the statistical analysis to show the relation between selected indicators of sustainable development.

\section{Results and Discussion}

The increasingly formalization of the African economy and the very fast-growing youth population and increase in urban development is expected to lead over $50 \%$ of Africans, moving to large cities by the end of 2050 . The results of own research carried out on-site within three African countries indicate the most important issues and problems related to sustainable development. The link between sustainable development and prosperity (living conditions, environment), energy and food security showed what is the current situation in African countries and what development directions should be taken.

\subsection{Energy - Choices for environment and development}

Africa is the second largest continent, with a population of over 1.3 billion people, whose consumption is systematically increasing. Only $24 \%$ of Africans living in sub-Saharan Africa have access to electricity, while the energy generation capacity of Africa (excluding South Africa) is only 28 gigawatts, equal to that of Argentina alone. Due to the continuous increase in energy demand, lack of availability of sufficient resources, the use of fossil fuels; long-term energy demand and supply forecasts are of prime importance in Africa. Broadening economies, population growth residential, international trade, the demand for commercial energy, and transport issues with the resulting constantly growing demand for energy will increase over the next few decades by over $40 \%$ (data for 2010-2040) and in Africa by $45 \%$. The energy industry and sector in Africa have great opportunities, huge growth potential, but these opportunities will be costly, and to take advantage of these opportunities and structures, various incentives need to be introduced to support the development of this industry and this sector. The economic growth required higher level of energy demand, so the direction of government action is to improve the use of various technologies aimed at more efficient use of fuel to increase energy efficiency (Ibrahiem 2018). The national governments of individual African countries have a key role to play in guaranteeing and making sure that this development will occur; policies implemented at the general government level should prepare local markets for the entry of private investors and properly promote regional integration to enhance savings on capital spending (World Economic Forum, 2016).

\subsection{Species and ecosystems - Resources for development}

Pollution of the natural environment, including soil, arable land, surface water and groundwater, as well as other coastal zones with chemicals derived from human activities is one of the most serious threats to the natural environment in many countries and the health of its citizens and inhabitants. The systematic population growth and progressive urbanization resulting from development have contributed significantly to the current strong, even alarming pollution in Africa. Emissions from transport by old, substandard cars, transported dust and open combustion of various materials (tires, plastics and other trash) contribute significantly to air pollution in Africa (Fayiga et al. 2018). The interplay between the dynamics of human population growth and the environment were often perceived rather superficially, whereas these relations are in fact quite complex and are characterized by specificity that should be thoroughly studied (Sherbinin 2007). Sprawling urban development has irrevocable ecological affects, such as, desertification and deforestation, other transformations. In towns and urban areas, rivers, and watercourses become disposal sites for human waste and residues, putting the 
populations at higher risk from water-borne diseases (for example, the well-known crisis of cholera disease in Guinea Conakry in August 2012) and polluting the environment over all (Borowski, 2017). In Conakry the urban area is systematic undergoing continuous growth (Traore, Watanabe 2017). More people residing in urban areas mean a more significant amount of waste is generated.

With the systematic, continuous rise in the African population and a growing number of people (especially the young generation) moving to urbanized areas, the quantity of solid waste produced is rapidly increasing. Many municipalities cannot manage to deal with the disposal of such large quantities of solid waste in a sanitary manner, such as in landfills. Moreover, due to the systematically growing problem of air pollution on atmosphere and natural environment, it is necessary to continue to monitor developments and long-term trends in air pollution and chemical precipitation in different types of ecosystems.

\subsection{Food security - Sustaining the potential}

There are many examples of countries suffering from food uncertainty in sub-Saharan Africa. Some with catastrophic consequences. Food insecurity is not only about insufficient food, production, and intake, but it is also about the lack of quality or nutritional worth of the food. The challenge and opportunities facing African countries are in fact an important and ere key to alleviating food insecurity and problems all over the world.

Guinea was well-known as a food exporter, especially banana. On the eve of independence, Guinea was a pioneer of banana export. In the post-independence era, there was a total collapse of the banana industry. With the ongoing changes in climate, food incertitude is likely to be more widespread particularly among micro and smallholder and subsistence farm households in sub-Saharan Africa (Tibesigwa, Visser, 2016). Nowadays, Guinea imports an estimated third of the rice it consumes each year. Weak links between markets and farmers have reduced overall productivity and profitability in agriculture. This situation can be characterized by limited access to reliable, high-quality seeds, planting methods, fertilizers and manure, deficiency of information on new agrarian technologies, know-how and best practices. Research indicates that consistently poor economic performance has negatively impacted on poverty reduction and human development. All research indicates that low human development and a high level of pollution is the result of the financial situation. Guinea continues to be one of the poorest countries in the world, and it is included among the lowest-performing countries in regard to human development in the UNDP Human Development Index (from 188 positions Guinea took 183, in the ranking surveyed in 2016) as shown in the Human Development Reports.

The economy of Ethiopia is dependent on agriculture, which contributes $43 \%$ of the Gross Domestic Products (GDP) and $90 \%$ of exports. However, only five percent of the land is irrigated, and crop yields from small farms are below regional average. Sensitivity to climate change is extremely important in this case, mainly to problems resulting from drought and lack of access to water (problems with irrigation of crops). Therefore, it is very important to ensure the sustainability of the water supply for irrigation of the fields (Emmanouil et al. 2021). The level of farms depends on many factors, including the level of education of people working on the land, socio-economic factors or access to drought-resistant plant varieties (Bedeke et al. 2020; Balehey 2018). Market linkages are weak and the use of better and revised seeds, fertilizers and pesticides coupled with primitive planting methods restrain progress. In spite of these challenges, agriculture-led economic growth that is linked to improved maintenance, living standards and nutrition 
can prevent a long-lasting denouement to Ethiopia's chronic poverty and food uncertainty. Ethiopia's Human Development Index (HDI) and its related ranking have not changed significantly during the last decades. Although Ethiopia is one of the ten countries globally that has achieved the most substantial absolute gains in its HDI over the last few years, it still indicates high position 173 out of 188 countries listed in the latest United Nations Development Programme (UNDP) Human Development Report.

Egyptian agricultural husbandry over the past 40 years has improved efficiency, output, and exports, and gaining for low-proceeds Egyptians. Agriculture and the agricultural sector in the broad sense is an important ingredient in the Egyptian economy. The agriculture sector in Egypt is characterized by small farms, which use relatively basic practices that do not meet internationally recognized standards. Agriculture in Upper Egypt is characterized by unsustainable farming practices and a lack of the use of market intelligence. Improving agriculture in Upper Egypt is necessary, as farmers in this region need to meet the quality standards required by international markets if they are to increase export volumes (Ahmed, Sallam 2020). For instance, farmers tend to misuse and over-use agricultural chemicals, employ outmoded technologies and tools for land cultivation, preparation, irrigation, and harvesting. As a result, farming practice have raised production costs, decreased yields, reduced soil fertility, and limited marketing opportunities. In addition, the Egyptian agricultural sector is limited by the lack of refrigeration infrastructure, transport systems, and market information. In Egypt, local administrative districts differ in terms of the division of labour into three types of activity: agriculture, industry and services. It hinges on the nature of each district as well as the prevalent activity. Accordingly, in the urban governorates in Lower Egypt, services have the highest division of labour, and the industrial operation comes in second place and finally the agricultural operation with the lowest share of labour, while in Upper Egypt, the agricultural work is the major recipient of the labour force.

\subsection{Sustainable development factors}

In order to determine the coherence of the three key elements constituting sustainable development: issue of environmental protection, issue of economic growth and issue of social inclusion, which are interrelated and interlocking with each other and all extremely important for achieving the well-being of individuals and societies as a whole, research was conducted.

We spread the issue of sustainable development over three major key elements indicated in the previous paragraph: the first group is environmental sustainability, the second constitutes economic sustainability, and the third, social sustainability. Each of these plays an essential role in terms of the sustainable development of agriculture, the economy and society. Tables from 1 to 3 show the most critical factors of sustainable development. 
Table 1. The first group of Sustainable Development

\begin{tabular}{ccccc}
\hline HDI rank & Country & \multicolumn{4}{c}{ Environmental sustainability } \\
\hline & & $\begin{array}{c}\text { Renewable energy consumption } \\
\text { (\% of total final energy } \\
\text { consumption) }\end{array}$ & $\begin{array}{c}\text { Carbon dioxide emissions } \\
\text { Per capita (tonnes) }\end{array}$ & $\begin{array}{c}\text { Forest area } \\
\text { (\% of total } \\
\text { land area) }\end{array}$ \\
\hline 26 & France & 13.5 & 5,2 & 31,2 \\
29 & Italy & 16.5 & 5,6 & 31,8 \\
35 & Poland & 11.1 & 9.1 & 30.8 \\
38 & Portugal & 27.2 & 5.0 & 34,6 \\
54 & Turkey & 12.8 & 5.2 & 15.2 \\
61 & Georgia & 28.7 & 2.6 & 40,6 \\
81 & Armenia & 18.8 & 1,9 & 11,7 \\
95 & Tunisia & 12.6 & 2,7 & 6,8 \\
102 & Jordan & 3.2 & 2,4 & 1,1 \\
116 & Egypt & 5.5 & 2.4 & 0.1 \\
173 & Ethiopia & 93.5 & 0.1 & 12.5 \\
177 & Guinea & 76.3 & 0.3 & 25.9 \\
182 & Sierra Leone & 77.7 & 0,1 & 43,1 \\
\hline
\end{tabular}

Table 2. The second group of Sustainable Development

\begin{tabular}{ccccc}
\hline HDI rank & Country & \multicolumn{3}{c}{ Economic sustainability } \\
\hline & & $\begin{array}{c}\text { Natural resource } \\
\text { depletion (\% of GNI) }\end{array}$ & $\begin{array}{c}\text { Adjusted net savings } \\
\text { (\% of GNI) }\end{array}$ & $\begin{array}{c}\text { Research and development } \\
\text { expenditure (\% of GDP) }\end{array}$ \\
\hline 26 & France & 0.0 & 8,9 & 2,2 \\
29 & Italy & 0.0 & 6,4 & 1,4 \\
35 & Poland & 0.7 & 10,5 & 1,2 \\
38 & Portugal & 11.8 & 6,4 & 1,4 \\
54 & Turkey & 0.3 & 12,1 & 1.0 \\
61 & Georgia & 0.7 & 6,4 & 0,3 \\
81 & Armenia & 2.9 & $-4,2$ & 0,2 \\
95 & Tunisia & 1.6 & $-8,3$ & 0,6 \\
102 & Jordan & 0.1 & 3,3 & 0,7 \\
116 & Egypt & 6.4 & 3,6 & 0.7 \\
173 & Ethiopia & 11.2 & 8,4 & 0.6 \\
177 & Guinea & 19.2 & $-10,2$ & --- \\
182 & Sierra Leone & 12.9 & $-20,3$ & -- \\
\hline
\end{tabular}


Table 3. The third Group of Sustainable Development

\begin{tabular}{ccccc}
\hline HDI rank & Country & \multicolumn{4}{c}{ Social sustainability } \\
\hline & & $\begin{array}{c}\text { Population in } \\
\text { multidimensional poverty } \\
(\%)\end{array}$ & $\begin{array}{c}\text { Old-age (ages } 65 \text { and older) } \\
\text { dependency ratio } \\
\text { (per 100 people ages 15-64) }\end{array}$ & $\begin{array}{c}\text { Income quintile ratio } \\
\text { Average annual } \\
\text { change (\%) }\end{array}$ \\
\hline 26 & France & --- & 40.4 & 1.4 \\
29 & Italy & --- & 45.8 & 1.0 \\
35 & Poland & --- & 37.0 & -0.6 \\
38 & Portugal & --- & 44.3 & -0.7 \\
54 & Turkey & --- & 18.0 & -0.3 \\
61 & Georgia & 0.1 & 29.5 & -0.8 \\
81 & Armenia & 0.1 & 26.1 & -0.7 \\
95 & Tunisia & 0.3 & 19.0 & -0.8 \\
102 & Jordan & 0.2 & 8.2 & -1.6 \\
116 & Egypt & 1.9 & 10.2 & -0.1 \\
173 & Ethiopia & 49.8 & 6.4 & 1.4 \\
177 & Guinea & 37.3 & 5.4 & -2.5 \\
182 & Sierra Leone & 29.7 & 5.2 & -2.4 \\
\hline
\end{tabular}

Terms and meanings of elements shown in the included tables above:

a. Group of indicators concerning the issue of environmental sustainability Consumption of renewable energy: Share of renewable energy calculated in relation to total final energy consumption. Renewable sources include geothermal, hydroelectric, tides, wind, solar, biomass, and biofuels.

Carbon dioxide emissions per capita: Human-originated carbon dioxide emissions stemming from gas flaring, burning of fossil fuels, plus the production and manufactured of cement, divided by the population counted in the middle of the year. Includes carbon dioxide exuded by forest and wood biomass through the diminution of forest areas.

Forest area: Land range more than 0.5 hectares with a woody perennial plant exceeding its height than 5 meters as well as a canopy cover of over $10 \%$ of concerned area or deciduous and coniferous arbour capable of reaching these thresholds on site. Excludes land predominantly under rural or urban land use, tree standing in agricultural production systems (for instance, in agroforestry systems and fruit plantations) and trees in urban parks, pleasure ground and gardens. Areas under reforestation that have not yet achieved but are expected to achieve a canopy cover of $10 \%$ and a tree height of $5 \mathrm{~m}$ are included, as are temporarily unstacked areas resulting from human intervention or natural causes that are expected to renovate and recover.

\section{b. Economic sustainability group of index}

Natural resource depletion: Monetary expression of mineral, energy, forest and air exhaustion, expressed as a percentage of gross national income (GNI).

Adjusted net savings (ANS): Called genuine savings can be described as net national savings plus education costs and minus energy depletion, net forest reduction, mineral depletion, and carbon dioxide and particulate emissions destruction. Net national savings according to economic and tax principles are equal to the gross national savings 
(being the sum of gross savings of individual institutional sectors) reduced in a given year by the value of the use of fixed assets.

Research and development expenditures $(\boldsymbol{R}+\boldsymbol{D})$ : Real investment outlays (both private and public) for creative work systematically undertaken to increase and acquire knowledge, including knowledge of human and cultural dimensions, and society, and to creatively apply the acquired knowledge to find new solutions. Financing research and development is primarily the financing of research included in the group of basic research, in addition to applied research and financing of experimental development.

\section{Social sustainability group of index}

Income quintile ratio, average annual change: Change in the ratio of the average income of the wealthiest $20 \%$ of the population to the average income of the highly deficient $20 \%$ of population in a given country between 2000 and 2014 divided then by the number of years taken into account.

Population in multidimensional and multivariate hardship and poverty, average annual change: percentage alteration of the population in multidimensional poverty in the population over 2005-2014, divided by a respective number of years.

Old-age dependency ratio: the proposed proportion of the population ages 65 and older to the population ages 15-64, explicit as the number of domestics per 100 people of working age (ages 15-64).

\subsubsection{Pearson correlation}

To show the relationships between variables related to sustainable development the Pearson's correlation statistical method was employed overall, including in the quantitative research. Correlation is a typical and commonly used statistical analysis based on a two-dimensional variable, which measures the strength of the relationship and coupling occurring between two different variables and indicates the trends that occur between these relationships. In terms of the strength of relationships, the value of the correlation coefficient varies between +1 and -1 . A value of \pm 1 indicates that there is an ideal degree of relationship between the variables of the par. In the case that the correlation coefficient value approaches 0 , the relationship between the two variables will be weak. On the basis of these three main groups of factors, it can be determined whether there are any relationships between the level of development of the studied countries and the socio-environmental situation, and whether there are relationships between individual elements. For this purpose, the occurring correlations were examined.

The sign of the coefficient indicates the course and trend of the association; a sign plus (+) indicates a positive relationship and a sign minus $(-)$ indicates a negative relationship. Pearson $r$ correlation is the most popular and widely utilized correlation statistic to measure the grade of the relationship between linearly tied variables (Cohen, Cohen, West \& Aiken, 2013).

Pearson correlation coefficient is calculated by using the following equation (1) (Zhou, 2016).

$$
r_{x y}=\frac{\sum\left(x_{i}-\bar{x}\right) \sum\left(y_{i}-\bar{y}\right)}{\sqrt{\sum\left(x_{i}-\bar{x}\right)^{2}} \sqrt{\sum\left(y_{i}-\bar{y}\right)^{2}}}
$$

Where $r$ - correlation coefficient of $x$ and $y$; 
$\bar{x}=\frac{1}{n} \sum_{i=1}^{n} x_{i}$ denotes the mean of $x ;$

$\bar{y}=\frac{1}{n} \sum_{i=1}^{n} y_{i}$ denotes the mean of $y$.

In table 4 are presented a value of selected factors indicated the level of sustainable development. In table 5, there are results of the Pearson correlation.

Table 4. Value of sustainable development selected factors

\begin{tabular}{lccccc}
\hline \multicolumn{1}{c}{ Country } & $\begin{array}{c}\text { Human } \\
\text { Development } \\
\text { Index }\end{array}$ & $\begin{array}{c}\text { old-age } \\
\text { dependency } \\
\text { ratio }\end{array}$ & $\begin{array}{c}\text { natural } \\
\text { resources } \\
\text { depletion }\end{array}$ & $\begin{array}{c}\text { renewable } \\
\text { energy } \\
\text { consumption }\end{array}$ & CO $_{2}$ emissions \\
\hline France & 26 & 40.4 & 0.0 & 13.5 & 5,2 \\
Italy & 29 & 45.8 & 0.0 & 16.5 & 5,6 \\
Poland & 35 & 37.0 & 0.7 & 11.1 & 9.1 \\
Portugal & 38 & 44.3 & 11.8 & 27.2 & 5.0 \\
Turkey & 54 & 18.0 & 0.3 & 12.8 & 5.2 \\
Georgia & 61 & 29.5 & 0.7 & 28.7 & 2.6 \\
Armenia & 81 & 26.1 & 2.9 & 18.8 & 1,9 \\
Tunis & 95 & 19.0 & 1.6 & 12.6 & 2,7 \\
Jordan & 102 & 8.2 & 0.1 & 3.2 & 2,4 \\
Egipt & 116 & 10.2 & 6.4 & 5.5 & 2.4 \\
Ethiopia & 173 & 6.4 & 11.2 & 93.5 & 0.1 \\
Guinea & 177 & 5.4 & 19.2 & 76.3 & 0.3 \\
Sierra Leone & 182 & 5.2 & 12.9 & 77.7 & 0,1 \\
\hline
\end{tabular}

Example of calculating index of Pearson correlation for two variables: Human Development Index $(x)$ and old-age dependency ratio $(y)$

\begin{tabular}{cc}
\hline$X_{i}$ & $Y_{i}$ \\
\hline$X 1=26$ & $Y 1=40.4$ \\
$X 2=29$ & $Y 2=45.8$ \\
$X 3=35$ & $Y 3=37.0$ \\
$X 4=38$ & $Y 4=44.3$ \\
$X 5=54$ & $Y 5=18.0$ \\
$X 6=61$ & $Y 6=29.5$ \\
$X 7=81$ & $Y 7=26.1$ \\
$X 8=95$ & $Y 8=19.0$ \\
$X 9=102$ & $Y 9=8.2$ \\
$X 10=116$ & $Y 10=10.2$ \\
$X 11=173$ & $Y 11=6.4$ \\
$X 12=178$ & $Y 12=5.4$ \\
$X 13=182$ & $Y 13=5.2$ \\
\hline
\end{tabular}


Table 5. Coefficient of Pearson Correlation

\begin{tabular}{llllll}
\hline & \multicolumn{4}{c}{ Pearson Correlation (N=13) } \\
\cline { 2 - 6 } & $\begin{array}{l}\text { Human } \\
\text { Developme } \\
\text { Index }\end{array}$ & $\begin{array}{l}\text { old-age } \\
\text { dependency } \\
\text { ratio }\end{array}$ & $\begin{array}{l}\text { natural } \\
\text { resources } \\
\text { depletion }\end{array}$ & $\begin{array}{l}\text { renewable energy } \\
\text { consumption }\end{array}$ & $\begin{array}{l}\mathbf{C O}_{2} \\
\text { emissions }\end{array}$ \\
Human Development Index & 1.0000 & $-0.8812^{*}$ & $0.7135^{*}$ & 0.7778 & $-0.8589^{*}$ \\
\hline $\begin{array}{l}\text { old-age dependency ratio } \\
\text { natural resources depletion }\end{array}$ & & 1.0000 & -0.4627 & -0.4954 & $0.7705^{*}$ \\
$\begin{array}{l}\text { renewable energy } \\
\text { consumption }\end{array}$ & & 1.0000 & 0.8016 & -0.5889 \\
$\mathrm{CO}_{2}$ emission & & & & 1.0000 & -0.6513 \\
\hline
\end{tabular}

*- Indicated correlation coefficients are calculated with statistical significance $a<0.05$

The research results showed that there is a very strong negative correlation between the country's development and the level of $\mathrm{CO}_{2}$ emissions (-0.8589), which means that the more developed the country (it occupies a better position in the HDI ranking), the greater the carbon dioxide pollution. This is a negative effect of industrialization in countries with high social development. Urbanization and industrialization have a significant impact on energy consumption and $\mathrm{CO}_{2}$ emissions, but their relationships vary at different stages of economic development including industrialization and income ( $\mathrm{Li}$, Lin 2015; Lin et al. 2017; Dong et al. 2019). According to some empirical studies, energy efficiency and economic development have shown a square U-shaped relationship, indicating that the country's long-term energy efficiency will first fall and then increase during economic activity (Pan et al. 2019; Rasoulinezhad, Saboori 2018). Moreover, our analysis of the research, indicated in the tables above, suggests that there is a linkage in the correlation between variables:

a. extremely strong correlation (from 0.8 to 1.0 very strong positive correlation; from -0.8 to -1.0 very strong negative correlation)

- the less developed the country, the smaller is the share of older people in society,

- the more developed country, the smaller is the level of natural resources depletion,

- the less developed the country produces less $\mathrm{CO}_{2}$ emissions,

- in the countries where the share of old-age people in the society is higher, the $\mathrm{CO}_{2}$ emissions are also higher which shows that negative $\mathrm{CO}_{2}$ emissions have no strong influence on age structure.

b. A strong correlation (positive strong correlation when the coefficient is from 0.6 to 0.8 ; from -0.6 to -0.8 strong negative correlation)

- renewable energy consumption increases in less developed countries,

- natural resource depletion increases in countries with lower $\mathrm{CO}_{2}$ emissions.

\section{Conclusions}

The research carried out by the authors allows one to conclude that in their estimation sustainable development and ecological security factors are key factors that play a particular role in implementing the concept of sustainable development in agriculture. This estimation can supply a foundation to investigate changes to cultivation and livestock systems at the field scale alongside proper and essential agronomic, economic, technical, environmental and policy changes.

While modern and progressive technologies have led to rise in input factors such as capital, fertilizers, pesticides, minerals, they have also accelerated environmental 
degradation. In Africa, countries' sustainable development is a way of attaining a superior level of life and welfare. Africa has understood this and as a consequence, has accepted the quest for sustainable development as a pressing imperative that requires serious attention. In addition, it will increase food security.

Innovative access to sustainable development in agriculture makes it possible to lead and drive new production techniques and technologies that meet with environmental requirements, ensure economic viability, take into account animal prosperity and make farmers' jobs easier.

It is also important to pay attention to increasing prosperity and to the maintenance of good health in poorer countries to increase the ratio of older people in society.

Increasing prosperity is not only about agriculture and food, but also about energy. Increasing access to clean energy (clean air, no pollution) is key to sustainable development.

\section{References}

1. Ahmed O, Sallam W. Assessing the Potential of Improving Livelihoods and Creating Sustainable Socio-Economic Circumstances for Rural Communities in Upper Egypt. Sustainability. 2020; 12(16):6307. https://doi.org/10.3390/su12166307.

2. Bachner, G., Bednar-Friedl, B. \& Knittel, N. (2019). How does climate change adaptation affect public budgets? Development of an assessment framework and a demonstration for Austria. Mitig Adapt Strateg Glob Change, 24, 1325-1341, https://doi:10.1007/s11027-019-9842-3

3. Balehey, S., Tesfay, G. \& Balehegn, M. Traditional gender inequalities limit pastoral women's opportunities for adaptation to climate change: Evidence from the Afar pastoralists of Ethiopia. Pastoralism 8, 23 (2018). https://doi.org/10.1186/s13570-018-0129-1

4. Batlle, J. V. I. (2015). Exposures and effects in the marine environment after the Fukushima accident. Annals of the ICRP, 44(1_suppl), 331-346. https://doi.org/10.1177/0146645315576099

5. Bedeke, S.B., Vanhove, W., Wordofa, M.G. et al. Vulnerability to climate change among maize-dependent smallholders in three districts of Ethiopia. Environ Dev Sustain 22, 693718 (2020). https://doi.org/10.1007/s10668-018-0215-y

6. Belk, R. (2013). Visual and projective methods in Asian research. Qualitative Market Research: An International Journal, 16(1), 94-107, https://doi:10.1108/13522751311289721

7. Bloom, N., Romer, P., Terry, S. J., \& Van Reenen, J. (2021). Trapped factors and China's impact on global growth. The Economic Journal, 131(633), 156-191. https://doi.org/10.1093/ej/ueaa086

8. Borowski, P. F. (2017). Environmental pollution as a threats to the ecology and development in Guinea Conakry. Ochrona Srodowiska i Zasobow Naturalnych, 28(4), 27-32, https://doi:10.1515/oszn-2017-0026

9. Borowski, P. F. (2020). Nexus between water, energy, food and climate change as challenges facing the modern global, European and Polish economy. AIMS Geosciences, 6, 397-421.

10. Boserup, E. (2017). The conditions of agricultural growth: The economics of agrarian change under population pressure. Routledge.

11. Chavas, J. P. (2017). On food security and the economic valuation of food. Food Policy, 69, 58-67, https://doi:10.1016/j.foodpol.2017.03.008

12. Chen, G. Q., \& Wu, X. F. (2017). Energy overview for globalized world economy: source, supply chain and sink. Renew Sust Energ Rev, 69, 735-749, https://doi: 10.1016/j.rser.2016.11.151

13. Chu, H., \& Ke, Q. (2017). Research methods: What's in the name?. Libr Inform Sci Res, 39(4), 284-294, https://doi:10.1016/j.lisr.2017.11.001. 
14. Cohen, J., Cohen, P., West, S. G., \& Aiken, L. S. (2013). Applied multiple regression/correlation analysis for the behavioral sciences. Routledge.

15. Creswell, J. W., \& Creswell, J. D. (2017). Research design: Qualitative, quantitative, and mixed methods approaches. Sage publication.

16. Dong, F., Wang, Y., Su, B., Hua, Y., \& Zhang, Y. (2019). The process of peak $\mathrm{CO}_{2}$ emissions in developed economies: A perspective of industrialization and urbanization. Resources, Conservation and Recycling, 141, 61-75. https://doi.org/10.1016/j.resconrec.2018.10.010

17. Duan, W., Oleszczuk, P., Pan, B. et al. Environmental behavior of engineered biochars and their aging processes in soil. Biochar 1, 339-351 (2019). https://doi.org/10.1007/s42773-019-00030-5

18. Emmanouil S, Philhower J, Macdonald S, Khadim FK, Yang M, Atsbeha E, Nagireddy H, Roach N, Holzer E, Anagnostou EN. A Comprehensive Approach to the Design of a Renewable Energy Microgrid for Rural Ethiopia: The Technical and Social Perspectives. Sustainability. 2021; 13(7):3974. https://doi.org/10.3390/su13073974

19. Fayiga, A.O., Ipinmoroti, M.O. \& Chirenje, T. Environmental pollution in Africa. Environ Dev Sustain 20, 41-73 (2018). https://doi.org/10.1007/s10668-016-9894-4

20. Freire-González, J., Vivanco, D. F., \& Puig-Ventosa, I. (2017). Economic structure and energy savings from energy efficiency in households. Ecol Econ, 131, 12-20, https://doi: 10.1016/j.ecolecon.2016.08.023

21. Fuglie, K. (2016). The growing role of the private sector in agricultural research and development world-wide. Global food security, 10, 29-38, https://doi:10.1016/j.gfs.2016.07.005

22. Hamann, S. (2020). The global food system, agro-industrialization and governance: alternative conceptions for sub-Saharan Africa. Globalizations, 17(8), 1405-1420. https://doi.org/10.1080/14747731.2020.1730050

23. Huang, Y., Partha, D. B., Harper, K., \& Heyes, C. (2021). Impacts of global solid biofuel stove emissions on ambient air quality and human health. GeoHealth, 5(3), https://doi.org/10.1029/2020GH000362

24. Ibrahiem, D.M. Road energy consumption, economic growth, population and urbanization in Egypt: cointegration and causality analysis. Environ Dev Sustain 20, 1053-1066 (2018). https://doi.org/10.1007/s10668-017-9922-z

25. Kasem, S., \& Thapa, G. B. (2012). Sustainable development policies and achievements in the context of the agriculture sector in Thailand. Sustain Dev, 20(2), 98-114, https://doi: $10.1002 /$ sd.467

26. Li, K., \& Lin, B. (2015). Impacts of urbanization and industrialization on energy consumption $/ \mathrm{CO}_{2}$ emissions: does the level of development matter?. Renewable and Sustainable Energy Reviews, 52, 1107-1122. https://doi.org/10.1016/j.rser.2015.07.185

27. Lin, S., Wang, S., Marinova, D., Zhao, D., \& Hong, J. (2017). Impacts of urbanization and real economic development on $\mathrm{CO}_{2}$ emissions in non-high income countries: Empirical research based on the extended STIRPAT model. Journal of Cleaner Production, 166, 952-966. https://doi.org/10.1016/j.jclepro.2017.08.107

28. Lo, C. (2021). China's Role in the Global Market Cycle. China's Global Disruption, 69-88. https://doi.org/10.1108/978-1-80043-794-420211006

29. Magis, K. (2010). Community resilience: An indicator of social sustainability. Society and Natural Resources, 23(5), 401-416, https://doi:10.1080/08941920903305674

30. Newsome, D., Moore, S. A., \& Dowling, R. K. (2012). Natural area tourism: Ecology, impacts and management (Vol. 58). Channel view publications.

31. Nir, D. (2012). Region as a socio-environmental system: an introduction to a systemic regional geography (Vol. 16). Springer Science \& Business Media.

32. Ochi, S., Leppold, C., \& Kato, S., (2020). Impacts of the 2011 Fukushima nuclear disaster on healthcare facilities: A systematic literature review. International Journal of Disaster Risk Reduction, Volume 42, p. 101350. https://doi.org/10.1016/j.ijdrr.2019.101350

33. Oerke, E. C., Dehne, H. W., Schönbeck, F., \& Weber, A. (2012). Crop production and crop protection: estimated losses in major food and cash crops. Elsevier. 
34. Pan, X., Chen, M., Ying, L. et al. An empirical study on energy utilization efficiency, economic development, and sustainable management. Environ Sci Pollut Res (2019). https://doi.org/10.1007/s11356-019-04787-x

35. Pretty, J. N., Morison, J. I., \& Hine, R. E. (2003). Reducing food poverty by increasing agricultural sustainability in developing countries. Agr ecosyst environ, 95(1), 217-234, https://doi:10.1016/S0167-8809(02)00087-7

36. Purwanto A, Sušnik J, Suryadi FX, de Fraiture C. Water-Energy-Food Nexus: Critical Review, Practical Applications, and Prospects for Future Research. Sustainability. 2021; 13(4):1919. https://doi.org/10.3390/su13041919

37. Rasoulinezhad, E., Saboori, B. Panel estimation for renewable and non-renewable energy consumption, economic growth, $\mathrm{CO}_{2}$ emissions, the composite trade intensity, and financial openness of the commonwealth of independent states. Environ Sci Pollut Res 25, 1735417370 (2018). https://doi.org/10.1007/s11356-018-1827-3

38. Ravenscroft, N. (2019). A new normative economics for the formation of shared social values. Sustain Sci 14, 1297-1307 https://doi.org/10.1007/s11625-018-0652-4

39. Rawluk, A., Ford, R., Anderson, N. et al. (2019). Exploring multiple dimensions of values and valuing: a conceptual framework for mapping and translating values for social-ecological research and practice. Sustain Sci 14, 1187-1200 https://doi.org/10.1007/s11625-018-0639-1

40. Rehbein, J. A., Watson, J. E., Lane, J. L., Sonter, L. J., Venter, O., Atkinson, S. C., \& Allan, J. R. (2020). Renewable energy development threatens many globally important biodiversity areas. Global change biology, 26(5), 3040-3051.

41. Rodrik, D. (2008). One economics, many recipes: globalization, institutions, and economic growth. Princeton University Press.

42. Scott, J. (2020), "Action, Society, and the Human Condition", Scott, J. (Ed.) The Emerald Guide to Talcott Parsons (Emerald Guides to Social Thought), Emerald Publishing Limited, Bingley, pp. 175-182. https://doi.org/10.1108/978-1-83982-654-220201010

43. Shao, Q. Paving ways for a sustainable future: a literature review. Environ Sci Pollut Res (2020). https://doi.org/10.1007/s11356-020-08247-9

44. Sherbinin, A. D., Carr, D., Cassels, S., \& Jiang, L. (2007). Population and environment. Annu. Rev. Environ. Resour., 32, 345-373.

45. Tibesigwa, B., \& Visser, M. (2016). Assessing gender inequality in food security among small-holder farm households in urban and rural South Africa. World Dev, 88, 33-49, https://doi:10.1016/j.worlddev.2016.07.008

46. Traore A, Watanabe T. Modeling Determinants of Urban Growth in Conakry, Guinea: A Spatial Logistic Approach. Urban Science. 2017; 1(2):12. https://doi.org/10.3390/urbansci102001

47. UNDP (2016), Human Development Report 2016. Human development for Everyone.

48. UNDP (2020), Human Development Report 2020. The next frontier.

49. World Economic Forum. (2016). Understanding Africa's energy needs.

50. Zhou, H., Deng, Z., Xia, Y., Fu, M., (2016). A new sampling method in particle filter based on Pearson correlation coefficient. Neurocomputing, Volume 216, 208-215, http://doi:10.1016/j.neucom.2016.07.036 